\title{
PERKEMBANGAN INDUSTRI BATIK “ PRING SEDAPUR “ DI DESA SIDOMUKTI KECAMATAN PLAOSAN KABUPATEN MAGETAN TAHUN 1970-2010
}

\author{
Ika Zahra Maulidina \& Debi Setiawati*
}

\begin{abstract}
Abstrak
Penelitian ini bertujuan untuk mengetahui perkembangan industri batik "pring sedapur" di Desa Sidomukti Kecamatan Plaosan Kabupaten Magetan tahun 1970-2010. Penelitian dilakukan selama lima bulan, pada bulan Februari sampai dengan bulan Juni 2011 berlokasi di Desa Sidomukti Kecamatan Plaosan Kabupaten Magetan. Sumber data berupa sumber data primer dan sekunder. Teknik pengumpulan data dengan wawancara dan observasi serta mencatat arsip dan dokumen. Analisa data dengan analisis interaktif yang berpegang pada tiga komponen, yaitu: reduksi data, sajian data, dan penarikan kesimpulan.

Hasil penelitian menunjukkan bahwa batik pring sedapur merupakan batik khas Magetan yang asal-usulnya dilatarbelakangi oleh keadaan sekitar Desa Sidomukti yang dikelilingi tumbuhan bambu. Sejak awal diperkenalkannya pada tahun 1970 seni batik khas Magetan ini mengalami perkembangan yang terus meningkat. Jumlah tenaga kerja yang semula 20 pengrajin kini menjadi 40 pengrajin, cara pembuatan batik tidak terpaku pada batik tulis saja tapi sudah mengenal batik cap dan batik printing. Sedangkan untuk pemasaran sudah lebih baik namun masih kalah dengan batik dari daerah lain yang lebih dikenal masyarakat luas seperti batik Solo, Yogyakarta dan Pekalongan. Keberadaan batik pring sedapur mulai diakui masyarakat Magetan sebagai ikon Kota Magetan. Upaya pelestarian juga sudah dilakukan oleh sebagian anggota masyarakat dengan dukungan dari Pemerintah Kabupaten Magetan.
\end{abstract}

\section{Kata Kunci: Batik, Industri}

\section{Pendahuluan}

Batik dengan berbagai macam coraknya adalah bagian dari karya budaya bangsa Indonesia sejak ratusan tahun yang lalu dan bukan berasal dari negara lain. Publik sudah tahu kalau batik berasal dan milik Indonesia. Apalagi jika dilihat dari teknik penampilan, latar belakang pemikiran, sejarah dan filosofi yang mengelilingi keberadaan batik itu sen-

Ika Zahra Maulidina adalah mahasiswa Program Studi Pendidikan Sejarah IKIP PGRI Madiun

Debi Setiawati adalah Dosen Program Studi Pendidikan Sejarah IKIP PGRI Madiun

52|Agastya Vol. 02 No. 02. Juli 2012 
diri, semua menunjukkan Indonesia Jawa misalkan Solo,Jogjakarta, Pekalongan,Cirebon (Yusuf Affendi, 1981:3).

Filosofi batik dari suatu daerah biasa dikenali melalui motifnya. Motif-motifnya yang ada mencerminkan karakter dan budaya masyarakat Indonesia. Misalkan batik Cirebon yang mempunyai ciri khas corak yang digunakan lebih bebas terutama

dalam menyusun komposisinya serta menciptakan pertalian yang serasi antara pengaruh Islam dengan

kesenian Budha Hindu Jawa yang sudah mentradisi (Yusuf Affendi, 1981:5). Harus diakui bahwa batik telah dikenal luas di dunia dan itu dianggap sebagai warisan Indonesia bagi dunia.

Seni batik yang ada di Magetan seperti Batik Pring Sedapur merupakan desain tradisional yang memiliki motif yang khas sebagai salah satu unsur dari kebudayaan nasional. Dari motif yang ada menunjukkan keadaan suatu daerah tertentu yang digambarkan pada kain yang menghasilkan motif. Hal tersebut dilakukan agar dengan memberi unsur yang beda maka motif tersebut mampu bersaing dengan

motif textil modern, karena saat ini kemajuan desain tekstil modern dapat mengalahkan seni batik tradisional yang mengakibatkan kemerosotan karya batik tradisional.

Pelestarian batik khas Magetan agar optimal, maka diperlukan

keterlibatan Pemerintah Daerah dan masyarkat Magetan karena hal tersebut merupakan langkah yang paling tepat dalam menjaga serta melestarikan budaya daerah. Batik merupakan Salah satu peninggalan budaya yang harus dilestarikan, seperti industri Batik di Desa Sidomukti yang sudah lama berdiri namun belum banyak yang mengenal serta belum ada yang menulis tentang keberadaan Dan perkembangan Industri ini. Untuk itu penelitian ini menarik untuk dilakukan. Bagaimana perkembangan industri batik "Pring Sedapur" di Desa Sidomukti Kecamatan Plaosan Kabupaten Magetan Tahun 1970-2010?

\section{Tinjauan pustaka}

\section{A. Batik}

Sejarah tekstil merupakan sejarah peradaban manusia sejak zaman Neolithikum. Tekstil atau kain merupakan keperluan hidup tiga serang di samping makanan dan perumahan bahkan sesudah manusia berhasil menggeser kulit binatang sebagai pakaian, maka tekstil menjadi salah satu unsur terpenting dalam dunia ekonomi dan kebudayaan. Melalui tekstil terungkaplah latar belakang kebudayaan gambaran suka duka, kemahiran berseni kemampuan bertukang, adat serta susunan alam lingkungan suatu bangsa. Bahkan Tekstil menunjukkan tingkat sosial melalui susunan warna dan ragam hias serta kehalusan bahan yang ditenun (Yusuf Affendi,1981:1). Batik merupakan salah satu bentuk tekstil yang ada di Indonesia. Dalam perjalanan sejarah kehidupan batik dari masa ke masa senantiasa mengalami pasang surut. Pada mulanya batik merupakan produk senirupa yang berfungsi sebagai busana yang digunakan untuk kalangan elite 
kraton. Lama kelamaan mampu menembus dinding kraton mempengaruhi daerah sekitar kraton hingga daerah pedesaan. Membatik telah menjadi alur karya budaya masyarakat Indonesia, terutama di Pulau Jawa. Telah sejak lama batik ditempatkan sebagai seni kain yang didukung oleh latar filsafat hidup dan kehidupan.

Batik merupakan kesenian warisan nenek moyang kita. Seni batik mempunyi nilai seni yang tinggi, perpaduan seni dan teknologi. Batik menarik perhatian bukan semata mata hasilnya, tetapi juga proses pembuatannya. Inilah yang kemudian membuat batik diakui oleh dunia. Tim Sanggar Batik Barcode menje-laskan bahwa kata batik (atau kata Batik) berasal dari bahasa Jawa "Mbatik", kata "mbat" dalam bahasa Jawa yang juga disebut "ngembat". Arti kata tersebut melontarkan atau melemparkan. Sedangkan kata "tik" biasa diartikan titik. Jadi, yang dimaksut batik atau mbatik adalah melemparkan titik berkali-kali pada kain. Menurut Soedjoko (dalam Tim Sanggar batik Barcode, 2010:4) batik berasal dari bahasa Sunda. Dalam bahasa Sunda, batik berarti menyunging pada kain dengan proses pencelupan.

Batik yang berpusat di Pulau Jawa dengan aneka ragam proses dan teknik penampilan serta latar belakang pemikiran. Batik tidak hanya dipandang sebagai proses pengerjaan tetapi disertai pengertian dan penampilan ragam hias dengan penggunaannya, maka dapat disimpulkan bahwa batik adalah suatu cara untuk melukis di atas kain dengan cara memberi titik - titik.

Menurut Destin Setiati dan Joko handoyo (2008:3-4) berdasarkan bentuk atau polanya, batik dibedakan menjadi dua sebagai berikut:

a. Batik tradisional

Menurut Kartini dkk (dalam Anindito Prasetyo, 2010:77) bahwa batik adalah hasil karya atau produk yang menggunakan lilin sebagai bahan bakar untuk menutup design atau motif yang diinginkan, sebelum produk atau hasil karya tersebut diproses sampai final. Sedangkan kata tradisional adalah berasal dari kata tradisi yang berarti sesuatu yang turun temurun dari nenek moyang atau menurut adat. Jadi batik tradisional adalah warisan dari nenek moyang yang menggunakan bahan, proses, dan motif yang tradisional. Batik tradisional Jawa disebut pula batik sogan yaitu batik yang menggunakan warna dasar soga (coklat) sebagai warna dominan, sedang-kan warna biru dan merah hanya sebagai warna pendukung.

b. Batik modern

Batik modern adalah semua macam jenis batik yang motif dan gayanya tidak seperti batik tradisional.berbeda dengan batik tradisional dalam pembuatan ornament atau isenisennya sesuai dengan gaya, keinginan dan kreatifitas seniman batiknya. Sedangkan dalam proses pewarnaan pada batik modern tidak tergantung pada 
pola-pola tertentu seperti pada batik tradisioanal. Namun desainnya dapat dibuat dengan beraneka macam corak. Batik modern juga menggunakan bahanbahan dan proses pewarnaan yang mengikuti perkembangan bahan-bahan pewarnaannya. Terkadang penggunaan canting sudah tidak diperlukan lagi, canting dapat diganti dengan kuas.

Untuk pewarnaan kadang diterapkan langsung dengan menggunakan kapas atau kain. Dengan kata lain, proses pembuatan batik modern hamper sama dengan batik tradisional hanya desain dan pewarnaannya terserah pada cita rasa seni pembuat. Bahkan dengan perkembangannya bahan dasar kain dan bahan kain berwarna, batik modern menjadi semakin bervariasi, seperti batik berbahan katun lurik, kain poplin, kain piyama, dan kain wol.

\section{B. Industri Batik}

Kata industri mempunyai cakupan makna yang sangat luas, yang telah banyak didefinisikan para ahli yang penjelasannyapun berbeda -beda. Menurut kamus besar bahasa indonesi industri adalah kegiatan memproses atau mengolah barang dengan menggunakan sarana dan peralatan misalnya mesin (Poerwadarminto,1995:377-376).

Industri adalah suatu usaha atau kegiatan pengolahan bahan mentah atau barang setengah jadi menjadi barang jadi yang memiliki nilai tambah untuk mendapatkan keuntungan Industri merupakan jenis usaha terutama bergerak dalam kegiatan proses pengubahan suatu bahan atau barang menjadi bahan atau barang lain yang berbeda bentuk atau sifatnya dan mempunyai nilai tambah atau nilanya menjadi lebih tinggi.

Jadi dapat disimpulkan industri adalah bagian dari proses produksi yang tidak mengambil bahan yang langsung dari alam, tetapi pengolahnya dahulu sehingga menjadi barang yang berniklai bagi masyarakat.

\section{Metode Penelitian}

Metode penelitian yang digunakan adalah metode penelitian kualitatif. Penelitian kualitatif adalah suatu penelitian yang ditujukan untuk mendiskripsikan dan menganalisis fenomena, peristiwa, aktivitas sosial, sikap, kepercayaan, persepsi, pemikiran orang secara individual maupun kelompok (Nana Syaodih Sukmadinata,2007:60).

A. Lokasi Penelitian

Sesuai dengan judul penelitian, maka lokasi yang dijadikan obyek penelitian adalah Desa Sidomukti Kecamatan Plaosan Kabupaten Magetan. Karena Desa ini satu-satunya desa pengrajin batik yang ada di Magetan.

B. Sumber Data

Dalam setiap penelitian sumber data sangatlah penting, sumber data sangatlah berguna bagi peneliti untuk memudahkan penelitian. Sumber data yang 
dipergunakan dalam penelitian

ini meliputi:

1. Sumber Data Primer

Data yang diperoleh secara langsung dari masya-rakat baik yang dilakukan melalui wawancara, observasi dan alat lainnya merupakan data primer (Joko Subagyo,2004:87). Sumber data ini diperoleh dari para informan yang terdiri dari warga dan tokoh masyarakat serta beberapa orang pendukung yang dianggap mengetahui obyek yang diteliti. Informan adalah orang yang diwawancarai, diminta informasi oleh pewawancara. Informan adalah orang yang diperkirakan menguasai dan memahami data, informasi, ataupun fakta dari suatu objek C. penelitian (Burhan Bungin, 2007:108). Sedangkan yang dimaksud dengan informan dalam penelitian ini yaitu orang-orang yang dapat D. memberikan informasi, dalam

hal ini adalah: a.) Pengusaha Industri dan karyawan merupakan pelaku dan b.) Masyarakat umum meliputi berbagai profesi.

Adapun cara mengumpulkan data dengan menggunakan snowball sampling. Snowball sampling digunakan bilamana peneliti ingin mengumpulkan data yang berupa informasi dari informan dalam salah satu lokasi, tetapi peneliti tidak tahu siapa yang tepat untuk dipilh sebagai narasumber (H.B Sutopo,2006:65).

2. Sumber Data Sekunder Sumber data sekunder

adalah data yang tidak langsung diperoleh dari sumbernya atau berasal dari bahan kepustakaan (Joko Subagyo,2004:88). Sumber data sekunder dapat diperoleh dengan melihat atau menga-mati langsung obyek yang mampu memberikan kete-rangan. Adapun sumber data yang dipergunakan adalah: a.) Foto - foto untuk dokumentasi dan b.) Peralatan untuk membuat batik.

Pengumpulan Data

Pengambilan data peneliti menggunakan teknik wawancara, observasi dan pencatatan dokumen.

Analisa Data

Menurut Miles dan Huberman dalam Brasowi dan Suwandi (2008:209) teknik analisis yang dilakukan dengan menggunakan teknik analisis data mencakup tiga kegiatan yang bersamaan yaitu reduksi data, penyajian data, dan menarik kesimpulan atau verifikasi. Sebagaimana bagan dibawah ini. 


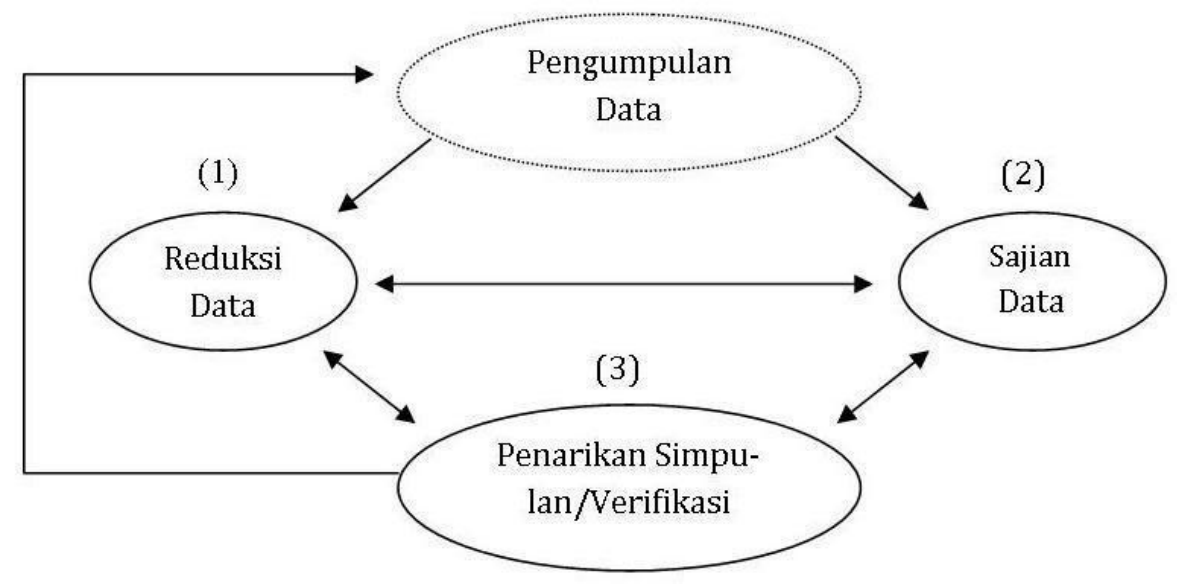

Gambar 1. Model Analisis Interaktif (H. B. Sutopo, 2006:120)

\section{Hasil penelitian}

Salah satu jenis batik khas dari Magetan adalah Batik Pring Sedapur. Pring adalah bahasa Jawa dari bambu dan sedapur adalah satu dapur, jadi konotasinyaadalahbambu yang sangat banyak. Batik ini adalah batik dengan motif pring atau bambu. Batik Pring Sedapur mempunyai ciri khusus pada motifnya, yakni, motif "Pring Sedapur" atau serumpum bambu. Motif ini diambil dari rumpunan tumbuhan bambu yang tumbuh mengelilingi kawasan Dusun Papringan di Desa Sidomukti, tempat batik tulis ini dibuat untuk pertama kalinya, sekitar tahun 1970-an. Ciri khas batik motif Pring Sedapur, berupa gambar rumpun bambu yang diatasnya ada gambar bulan.

1. Sejarah Awal Perkembangan Industri Batik (1970-1999)

Industri batik di Desa

Sidomukti menurut cerita Sukinah (55 tahun) warga masyarakat Desa Sidomukti tepatnya Dukuh
Papringan, industri batik sudah mulai ada sekitar tahun 70-an (wawancara 31 Mei 2011). Awal berdirinya industri batik berada di Dukuh Papringan yang semula hanya sebuah home industri yang hanya dikerjakan oleh ibu-ibu rumah tangga sebagai kegiatan mengisi waktu luang.

Industri batik di Desa Sidomukti mulai dirintis tahun 1970, jumlah pembatik saat itu hanya 4 orang. Dalam kegiatan produksinya masih menggunakan peralatan yang sederhana sekali, dan saat itu hanya batik tulis yang dapat dihasilkan. Sedangkan hasil produksinya cukup dijual ke pasarpasar sekitar Desa Sidomukti. Pada tahun 1970 batik Pring Sedapur sulit untuk menembus pasaran karena belum banyak orang yang mengenal produk ini. Selain belum dikenalnya produk ini juga buruknya perekonomian negara yang mengakibatkan daya beli masyarakat terhadap produk 
ini rendah karena yang terpenting bagi masyarakat adalah dapat memenuhi kebutuhan sehari-hari. Kegiatan membatik tersebut dilakukan dari tahun ke tahun. Kemudian pada tahun 1985 menurut cerita Umi (40 tahun) pimpinan industri batik di Desa Sidomukti (wawancara pada tanggal 31 Mei 2011) kegiatan membatik mulai dikenal dan diikuti oleh masyarakat sekitar. Kemudian pada tahun 1990 pengrajin batik yang semula hanya beberapa orang saja di tahun ini sudah mencapai kurang lebih 20 pengrajin. Dahulu industri batik dikerjakan hanya dirumah saja namun sekarang sudah berdiri sebuah industri kecil dengan jumlah pengrajin 20 orang yang tergabung dalam kelompok Sentra Batik Mukti Rahayu.

Walaupun pemasarannya belum begitu luas namun masyarakat sekitar industri batik sudah mengenal maka diharapkan sedikit banyak masyarakat dapat membantu dalam pengenalan dan pemasaran produk ini. Kemudian dengan mulai dikenalnya produk batik maka permintaan konsumen semakin meningkat, maka jumlah produknya perlu ditambah supaya permintaan konsumen terpenuhi. Dari sinilah mulai muncul banyak para pengrajin batik yang dahulunya hanya beberapa orang saja.

Bahan baku dan bahan pewarnaan semua didapat dari Solo. Solo dianggap kota paling dekat untuk memperoleh bahan baku, jadi dengan jarak yang dekat maka dapat mengurangi jumlah biaya produksi.

Sejarah motif Pring Sedapur berawal dari letak industri batik yang ada di Dusun Papringan dikelilingi pohon bambu maka dibuatkah motif Pring Sedapur yang berarti Serumpun Bambu untuk menggambarkan keadaan wilayah tersebut.

2. Masa Peningkatan Jumlah Produksi dan Pemasaran (19992010).

Menurut Sudarmi (35 tahun) seorang pengrajin batik (wawancara pada tanggal $31 \mathrm{Mei}$ 2011) pada masa ini industri batik mulai ada peningkatan baik di jumlah produksi maupun pemasaran. Pada tahun 2002 diadakan pelatihan dari Pemkab Magetan terhadap para pengrajin batik. Pelatihan tersebut bertujuan untuk meningkatkan mutu dari produk batik khas Magetan. Dengan adanya pelatihan tersebut maka didirikan kelompok pengrajin baru yang bernama Mukti Lestari yang berada di Dusun Guritan. Kelompok ini didirikan pada tahun 2006. Jadi di Desa Sidomukti ada dua industri batik yang tergabung dalam kelompok Mukti Rahayu dan Mukti Lestari. Jumlah pengrajin yang tergabung dalam kelompok Mukti Lestari adalah 20 pengrajin.

Tujuan didirikan kelompok baru adalah untuk memudahkan para pembeli bila ingin memesan batik Khas Magetan tersebut, karena sentra batik tersebut berada di kantor desa Sidomukti, 
jadi apabila ada pembeli bisa langsung datang ke Kantor Desa tersebut.

Namun dalam perkem-
Produksi besar-besaran dilakukan jika ada pesanan.

\section{Pembahasan} bangannya industri batik ini tidak berjalan lancar. Terbukti Batik pring sedapur merupakan pada tahun 2006 Pemkab kesenian warisan nenek moyang. Seni Magetan menginstruksikan se-batik mempunyai nilai seni yang mua Pegawai Negeri Sipil (PNS) tinggi, perpaduan seni dan teknologi. di lingkungannya memakai baju batik khas Magetan yaitu Pring Sedapur. Namun ironisnya order sebanyak 15.000 helai kain tidak belakang pemikiran. Jenis batik ada diberikan kepada kelompok dua macam yaitu batik tradisional dan perajin batik Desa Sidomukti batik modern. melainkan memesan dengan Industri batik Pring Sedapur di motif khas Magetan tersebut ke Desa Sidomukti khas Magetan Solo. Dengan alasan bahwa termasuk kategori industri kecil yang perajin dari Desa Sidomukti Lemah dalam permodalan dan dinilai tidak mampu memenuhi penyediaan tenaga terampil. Adanya order sebanyak itu dengan teknik kerjasama Dalam proses produksi batik yang masih batik tulis. dengan penghasil batik dari daerah Namun dari kejadian ini para Lain memungkinkan masuknya perajin melakukan unjuk rasa ke pengaruh seni dari luar daerah baik Kantor Pemkab Magetan dan teknik, desain, dan warna terhadap hasilnya Pemkab Magetan perkembangan senibatik khas memberikan bantuan berupa Magetan. Ditinjau dari jumlah tenaga satu paket alat produksi batik cap.

Pemkab berharap dengan diberikannya bantuantersebut diharapkan agar batik khas Magetan mampu bersaing di tingkat nasional. Namun pada kenyataannya keberadaan batik khas Magetan dengan motif Pring Sedapur dari tahun ke tahun semakin terpurukdi tingkat pasar lokal, akibat masuknya batik Solo dan Pekalongan. Jadi saat ini industri batik di Desa Sidomukti tetap berproduksi namun dengan skala kecil. kerja yang disesuaikan dengan jumlah produksi hal ini menggambarkan prospek batik khas Magetan di masa depan sebagai barang dagangan yang mempunyai potensi ekonomi yang menjajikan.

Berdasarkan sejarah awal berdirinya industri batik Magetan membuktikan bahwa masih ada beberapa anggota masyarakat yang mampumenggali, menemukandan mengembangkan unsur budaya lokal serta mewujudkannya dalam bentuk sebuah Industri kerajinan batik walaupun awal berdirinya dilakukan untuk kegiatan mengisi waku luang oleh ibu - ibu rumah tangga. Namun 
seiring berjalannya waktu industri tersebut mengalami peningkatan terbukti banyak warga yang mencoba untuk mempelajari proses pembuatan batik. Walaupun saat itu cara pembuatan masih menggunakan peralatan yang sederhana dan hanya dapat menghasilkan batik tulis namun dengan semakin banyak orang yang mengetahui diharapkan dapat membantu dalam pengenalan dan pemasaran produk ini.

Batik pring sedapur di Desa Sidomukti berdiri sekitar tahun 1970 . Pemberian nama Pring Sedapur diambil dari kondisi yang terjadi di daerah tersebut yang di sepanjang daerah tersebut banyak tumbuh tanaman bambu. Dengan menggunakan tangan-tangan terampil masyarakat setempat tumbuhan bambu dirubah menjadi suatu kerajinan yang disebut kerajinan anyaman. Dengan tumbuhnya tanaman tersebut dan dapat menghasilkan pendapatan bagi masyarakat setempat maka motif batik di beri nama tersebut dapat memberikan berkah bagi para pengrajin dan batik itu perkembangan yang terjadi pada industri batik khas Magetan. Baik dalam proses pembuatan yang sudah mengenal beberapa cara yaitu batik cap dan batik printing, serta pemasaran yang sudah banyak dikenal masyarakat. Walaupun masih ada kendala tapi sudah lebih baik dari sebelumnya.

Dari awal perkembangan industri batik pring sedapur selalu mengalami peningkatan dari tahun ke Pring Sedapur dengan harapan nama sendiri. Pada masa ini sudah banyak

tenaga kerja maupun pemasaran. Yang menjadi unggulan dari batik ini adalah motifnya, karena motif seperti ini belum ada didaerah lain. motif ini juga menggambarkan keadaan daerah tersebut jadi secara tidak langsung motif ini merupakan ungkapan para pengrajin atas keadaan yang ada disekitarnya. Dalam perkembangannya batik dijadikan ikon dari

kabupaten Magetan yang dapat membawa nama baik Magetan dimata daerah lain. Sedangkan untuk kekurangan dari perkembangan industri batik adalah pemasaran yang masih sulit, karena masih kalah dengan produk batik daerah lain seperti Pekalongan, Yogyakarta, dan Solo.

\section{Simpulan}

Batik pring sedapur merupakan batik khas Magetan yang dijadikan Ikon kota Magetan. Dalam perkembangannya, batik khas Magetan ini mengalami peningkatan, yang semula batik hanya sebagai pekerjaan sambilan kini telah menjadi pekerjaan pokok bagi ibu-ibu di Desa Sidomukti.

Tahun 1970-1999 terjadi peningkatan pada sektor tenaga kerja, Hasil produksinya cukup dijual dipasar-pasar sekitar Desa Sidomukti. Pemasaran pada tahun tersebut masih sulit karena belum banyak orang yang mengenal produk tersebut serta buruknya perekonomian pada saat itu yang mengakibatkan daya beli masyarakat rendah.

Pada tahun 1999-2010 terjadi peningkatan yang lebih baik karena tahun baik di bidang permodalan, Hasil produksinya sudah banyak, 
sudah mengenal cara pembuatan batik lain seperti batik cap dan batik printing. Pemerintah daerah juga sudah mulai memperhatikan keberadaan batik pring sedapur yang menjadi ikon kota Magetan dengan cara memberi pelatihan terhadap para pengrajin agar dapat meningkatkan hasil produksinya serta membantu dalam hal permodalan.

\section{Saran}

$\begin{array}{rrr}\text { Berdasarkan } & \text { hasil penelitian } \\ \text { yang dilakukan } & \text { dan dengan }\end{array}$ kesimpulan- kesimpulan yang diperoleh maka dapat dikemukakan implikasi dari penelitian ini adalah sebagai berikut bahwa dalam industri batik masih banyak masalah-masalah yang muncul dan harus diselesaikan agar hasil produk batik khas Magetan tersebut bisa meningkat dan meluas ditingkat pasar lokal.

Dengan berorientasi pada hasil penelitian tersebut di atas, maka penulis mempunyai saran dan harapan sebagai berikut:

1. Pemerintah Kabupaten Magetan, agar selalu memberikan perhatian terhadap industri khas Magetan agar hasilnya lebih baik dan membawa nama baik Magetan

2. Kepala Desa Sidomukti, agar selalu memberikan pengarahan terhadap masyarakatnya untuk selalu menjaga aset khas kota Magetan tersebut.

Bagi para pengrajin batik, agar selalu berkerja keras untuk menghasilkan produk yang berkualitas tinggi. 


\section{Daftar Pustaka}

Anindito Prasetyo.2010 .Batik. Yogyakarta:Pura Pustaka. Basri MS.2006. Metodologi Penelitian Sejarah. Jakarta:Restu Agung.

Basrowi dan Suwandi. 2008. Memahami Penelitian Kualitatif. Jakarta:Rineka Cipta.

Burhan Bungin. 2007. Penelitian Kualitatif:

Komunikasi,Ekonomi, Kebijakan Publik, dan Ilmu Sosial.Jakarta:Kencana

Cholid Narbuko dan Abu Ahmadi. 2003. Metodologi Penelitian .Jakarta:Bumi Aksara

Destin huru Setiati dan Joko Dwi Handoyo. 2008. Membatik. Yogyakarta: PT.Macanan Jaya Cemerlang.

Dharsono. 2007. Budaya Nusantara. Bandung: Rekayasa Sains.

Husaini Usman dan Purnomo Setiady Akbar. 2004. Metodologi Penelitian Sosial. Jakarta:Bumi Aksara.

Irsan Azhary Saleh.1986. Industri Kecil. Jakarta : kincir Buana.

Irwan Abdullah.2003. sangkan paran gender. Yogyakarta: Pustaka Pelajar Offset

Joko Subagyo.2004. metode Penelitian. Jakarta: rineka cipta.

Martono.1987.

pengetahuan

Dokumentasi dan

Perpustakaan sebagai Pusat Informasi. Jakarta: Karya Utama.
Moleong.L.J.2007. Metodologi penelitian kualitatif. Bandung: PT.Remaja Rodakarya.

Nana Syaodih Sukmadinata. 2007. Metodologi Penelitian Pendidikan. Bandung: PT. Remaja Rodakarya.

Rasjoyo.2008. Mengenal Batik Tradisional. Jakarta:Azka press.

Suharsimi Arikunto.2005. Manajemen

Penelitian. Jakarta:Rineka Cipta.

Sukardi.2003. metodologi Penelitian Pendidikan Kompetensi dan Praktiknya. Jakarta:Bumi Aksara.

Sutopo .H.B. 2006. Metodologi Penelitian kualitatif. Surakarta:Universitas Sebelas Maret.

Tim Sanggar Batik Barcode.2010. Batik. Jakarta: PT.Niaga Swadaya.

Yuswuf Affendi. 1981. seni Tenun Silungkang dan sekitarnya. Jakarta:Karya Utama 